\title{
Standardization of the formulas of discursive practice farewell in the national cooperative communicative behaviour ${ }^{1}$ \\ Atvadīšanās diskursa prakses standartformulas nacionālajā kooperatīvās saziņas uzvedībā
}

\author{
Alla Korolyova \\ Kyiv National Linguistic University \\ Velyka Vasylkivska St. 73, 03680, Kyiv, Ukraine \\ E-mail: allakor2008@gmail.com \\ Igor Korolyov \\ Research Department, Institute of Philology \\ Taras Shevchenko National University of Kyiv \\ Shevchenko Blvd. 14, 01601, Kyiv, Ukraine \\ E-mail: korolyovigor@gmail.com
}

This article offers characterisation of the standardization process of the discursive practice (DP) formulas denoting farewell in the national cooperative communicative behaviour (NCCB) of Ukrainians, Russians, Lithuanians and Americans (USA), grammaticalization of which has occurred depending on the dominant modes of this practice in each linguaculture. Here, we refine the definition of DP farewell as a standardised etiquette and ritual seminal construct (grammatical form / formula) of the NCCB of Ukrainians, Russians, Lithuanians and Americans, whereby the phatic closing phase of discursive situations is completed (the contact between the interlocutors is concluded, the interaction is finalized), in the process of which the interrelationships between the addresser and the addressee in a discursive space of cooperative or other interaction are predicated upon.

A new experimental procedure is proposed for identifying the standardized formulas of the dominants, characteristic of DP farewell in the four linguacultures. The linguistic experiment has enabled the authors to derive the productivity indices (PI) of modes of politeness / tolerance (MP / MT), neutrality (MN) and familiarity (MF) as means for each type of DP both in a particular linguaculture and for a particular DP farewell, regulating the NCCB of Ukrainians, Russians, Lithuanians and Americans.

On the basis of the derived PI of the modes of politeness / tolerance, neutrality and familiarity, we managed to capture that for DP farewell in NCCB of the representatives of the linguacultures under consideration, the circumnuclear zone of communicative consciousness of Ukrainians (MP / MT 0.36; MN 0.32), Russians (MP / MT 0.38; MN 0.41), Lithuanians (MP / MT 0.39; MN 0.35), and Americans (MP / MT 0.39; MN 0.3), formed on the basis of modes of politeness / tolerance, and neutrality, is universal. More

1 The article has been prepared within the scope of the scientific project «Ecolinguistic Modes of Discursive Space of Ukraine in the European Multicultural Continuum» (registration number 2020.02/0241) with the support of the National Research Foundation of Ukraine. 
considerable differences are expressed with the productivity indices of the mode of familiarity of DP farewell in NCCB of Americans (MF 0.31) and Lithuanians (MF 0.34), which belongs to the circumnuclear zone of their communicative consciousness, whereas in Ukrainians (MF 0.21) and Russians (MF 0.21) it takes the zone of near periphery.

Keywords: discursive practice farewell; standardized formula; national cooperative communicative behaviour; mode of politeness; mode of tolerance; mode of neutrality; mode of familiarity.

\section{Introduction}

Modern Linguistics and Communication Studies investigate the aspects of communicative activity of people, who represent different nations. Those investigations are connected primarily with the search for new instruments, mechanisms, ways and means of achieving harmonious and successful communication, as well as cooperation. Though this tradition used to be verified by many generations of scholars, nowadays it requires further development of a new research methodology (Sheygal 2000; Papaurèlytė-Klovienė 2007; Sternin 2015; Likhacheva 2017; Kalnača, Lokmane 2018; Korolyov 2018; Lauze 2018; Darginavičienė 2019). That is why, within the context of globalization, intensification of various forms of communicative activity and interaction, active development of international contacts, diplomatic relations, etc. urgently require a deeper scientific understanding of cognitive, semiotic and discursive phenomena, which represent the national cooperative communicative behaviour (NCCB) of representatives of linguacultures like Ukrainian, Russian, Lithuanian and American (the USA).

The choice of ethnic cultures for the analysis of the organization of modes of DP farewell is principally conditioned by the strategic trajectories of global geopolitics, the primary focus of which is currently on the representatives of the Ukrainian, Russian, Lithuanian and American societies. In connection with this, the main task of the humanitarian science is the need to identify and research those signs and models of communication, the modes of which will help to lower the degree of tension in the intercultural communicative behaviour of both politicians and ordinary nationals of these countries.

Describing the cultural specificity of the Baltic peoples, the American researcher Foster (2004, 208-209) stressed such traits of Lithuanians, in comparison with Latvians and Estonians, as openheartedness, frankness, and loquacity, manifesting themselves as a desire to express both positive and negative opinion, thus, we can state that the level of their straightforwardness and the emotionality of their speech behaviour is higher. The similar stereotyped characteristics of speech behaviour of Ukrainians are presented in the works of many other researchers (Shutova 2016).

Comparing the communicative behaviour of Ukrainians and Russians as the representatives of the Slavic peoples with the communicative behaviour of Lithuanians as those of the Baltic ethnic groups, in particular, in the discursive situations of farewell, it is necessary to take into account the long-term connection of Lithuania with Poland (156 years of a united Polish-Lithuanian state, the Polish-Lithuanian Commonwealth), as well as the fact that in some regions of the contemporary Republic of Lithuania, in particular, in the Vilnius region and the so-called Small Lithuania, Russians, Poles, Belarusians and Ukrainians 
live in different ratios (Mikhalchenko 1984, 51). Besides, all the Baltic countries (Lithuania, Latvia, and Estonia), especially their border territories, are inhabited by considerable numbers of Balts of the neighbouring nationalities (Latvians live in the north of Lithuania, and Lithuanians live in the south of Latvia, etc.) (Foster 2004, 206). The corresponding ethnic composition of the population is the macrostructure that defines the empirical material for a certain analysis, in particular, in the proposed article.

The linguistic foreshortening of the topicality of the object of scientific reflection deals with the necessity for a comprehensive study of the speech activity of a person as a whole and its communicative dimensions in particular, i. e. the need to answer those challenges that have not yet covered the whole problem: 1) how they are constructed and stored within the models / stereotypes of cooperative communicative behaviour within language / communicative consciousness of the linguistic personality; 2) how forecasting, planning and regulation of cooperative communicative behaviour is represented through cognitive-semiotic and discursive-pragmatic factors; 3) how universal constants and nationally valuable dominants are reflected in cooperative communicative behaviour of people who represent different linguacultures.

The target of the research is the discursive practice (DP) farewell, and the research subject is the standardization of the formulas in the modes of its configuration in NCCB of Ukrainians, Russians, Lithuanians and Americans.

The purpose of the present article is to compare the standardized formulas in the modes of DP farewell in NCCB of Ukrainians, Russians, Lithuanians and Americans and to identify it's dominant in each linguaculture.

\section{Research methods and materials}

In the current article, a complex of methods and procedures of analysis of the language material was used for the purpose of achieving the aim of the research. First and foremost, an anthropometric method (proposed as a tool for experimental study of communicative behaviour by Sternin (Sternin 2008, 24-25) using the tools of psycho- and sociolinguistic experiments in the form of linguistic interviewing), with the help of which 16203 responses (4356 - from Ukrainians, 4158 - from Russians; 3894 - from Lithuanians, 3795 - from Americans) to stimulus questions concerning typical speech forms (their sign-configurations), which are stereotyped and standardized for the communicative behaviour of informants in discursive situations of greeting, acquaintance, invitation, request, consent, praise / compliment, gratitude / appreciation, apology, sympathy / compassion / empathy / consolation, wish / desire, and farewell were obtained. This procedure, including the answers of respondents in the form of linguistic interviewing ${ }^{2}$, allowed deriving sign and verbal representatives, the standardized formulas of DP farewell (29 - in the Ukrainian NCCB; 31 - in the Russian one; 32 - in the Lithuanian one; and

2 The question "What speech forms of farewell / good-bye are typical for you in communication: polite / tolerant, neutral and familiar?" was offered to informants of each of the four studied linguacultures in Ukrainian, Russian, Lithuanian and English (for Americans). 
27 - in the American one) from the situations in question. Thus, respondents in the form of a pilot survey before a direct linguistic interview could anonymously answer questions related to sociolinguistic parameters, including gender, age, place of birth, nationality, mother tongue and language they mostly use in communication, their level of education, profession (specialty, position). It should be noted that the research results are relevant for the representatives of the Ukrainian, Russian, Lithuanian, and American linguacultures having medium and high social status, who identify themselves as Ukrainians, Russians, Lithuanians and Americans, and correspondingly have an average and high level of language and communicative competence.

The responses obtained from more than 100 informants aged 17-75 years from each of the studied linguacultures, mostly students, PhD students (Post-Doctoral researchers), employees of teaching facilities, representatives of the intellectual class and young professionals: scholars of language, legal practitioners, historians, sociologists, economists, computational professionals, mathematicians, medical workers, psychologists, were processed using the formula $\mathrm{N}=\mathrm{Ss} * \mathrm{n}$, where (N) sample size was calculated by the number of subjects and by the number of stimuli, Ss is the number of respondents, who participated in the research, and $\mathrm{n}$ is the number of stimuli, offered for response (Yagunova 2005, 28). Thus, the sample size for observation for the Ukrainian communicative culture is $132 * 4=528$, for the Russian one it is $126 * 4=504$, for the Lithuanian one $-118 * 4=472$, and for the American one $-115 * 4=460$.

The dominant modes of politeness / tolerance (MP / MT), neutrality (MN), and familiarity (MF) in NCCB of the representatives of the linguacultures under consideration are implied by the productivity indices (PI) of a particular mode of communication of each DP under study, in particular, that of farewell. The correlation between the modes (politeness and neutrality, neutrality and familiarity, politeness and tolerance, etc.), specifically, the dominant character of one of them in a particular discursive situation depends on the slot of frame scenario model of NCCB (Korolyov 2018b), which is linked with nonverbal elements of the process of communication, phonatory means - the elements of prosody (voice level, pitch, tempo, pronunciation features, and timbre), as well as on the specificity of (non-)institutional discursive space. Since the procedures of psycho- and sociolinguistic experiments did not presuppose including special separate questions to the respondents concerning the non-verbal semiotic matrix of NCCB, we set out the results of sign representation of verbal structures only, reflecting the communicative consciousness of the informants.

For each standardized formula DP farewell, singled out experimentally, as well as for each component of the word meaning / notion, the performance index may be derived (PI, by analogy to the derivation of the index of seme intensity (Sternin 2015, 109) as the relation of the number of those, who insulated or suggested this index to the number of the participants of the experiment). Thus, for the linguistic interviewing, the following principle of calculating PI for each model will be characteristic: if out of 100 responses a certain standardized formula of DP is given in 50 responses, then its PI is 0,5 , if in 5 responses, then its PI is 0,05 etc. Consequently, the corresponding criterion (semantic component, the DP 
itself, etc.) becomes a very important index not only for describing the structure of word meaning / notion, but also for the cognitive and discursive realization of a particular DP. By the PI principle, it is possible to range both semantic components and standardized formula cooperative DPs, defining their nuclear and peripheral taxonomy in the structure of the communicative consciousness of the representatives of different linguacultures.

\section{Discursive practice: farewell as a component of national cooperative communicative behaviour}

Interdisciplinary paradigm in the study of communication facilitated handling of numerous problems pertaining to communication process, relying not only on the forms and structure of languages, but orienting towards the content and the mechanism of ideation and creative (sensor and intuitive as well as intellectual and speech) activity of a personality as a special "state of consciousness", which is actualized and recreated in the sociocultural environment with the help of (and thanks to) communication (Dridze 1996, 149). From the linguistic perspective, as Nikolayeva (2000) notes, it is important to identify "unknown" and "latent" intentions in communication, caused by social, pragmatic, role-related, and individual psychological factors. That is why, we consider that the interest of researchers to cognitive and semiotic factors in interpersonal communication in different types of discourse is not accidental (Alefirenko 2007; Vasko 2019a, $2019 \mathrm{~b}$ ), and as important as elucidating an issue of the sign status of the national communicative behaviour of the interactants - representatives of a particular linguaculture - in a discursive space.

Interest in researches in the field of national communicative / discursive space activates processes related to the scientific systematization of the provisions and explanations in the field of ethnic specifics of communication (Hymes 1972; Krasnykh 2004). Analysing the national cooperative communicative behaviour of representatives of the Ukrainian, Russian, Lithuanian and American linguacultures (Korolyov 2018a, 2019), it is necessary to clarify such a significant phenomenon as a discursive space, within which a mono- and intercultural interaction is carried out: "The task of building a discursive/ communicative dimension becomes the formation of a single picture of the world, which contributes to the unity of the nation" (Pocheptsov 2001, 299).

The focus of cognitive semiotics is on the notion of discursive thinking, which Luriya $(1998,323)$ proposed a while ago, using the term discursive as a synonym for speech / language. By the term discursive consciousness, a scientist understands a mechanism that "allows one to delve into the ontology of things, go beyond the direct impression, organize their purposeful behaviour, uncover complex connections and relationships, unavailable for direct observation, and to pass information to another person".

From the perspective of cognitive discursive semiotics (Alefirenko 2007; Vasko 2019a; Korolyov 2018a; Sheygal 2000) we propose to consider national communicative behaviour, which is based on the concept of "national language personality" (Sedov 2004), which is its "semiotic centre" and the subject of 
discursive practices, representative of a particular ethnic community: a bearer of mentality, national character, language, national value dominants, etiquette and ritual norms and stereotypes (Korolyov, Domylivska 2020). It is possible to establish universal and specific features of the latter, in particular, by applying a formalized complex methodology for the comparative study of stereotyped national DP from the standpoint of cognitive semiotics, psycholinguistics and linguistic discourse study, which determine the methodological basis of this study, the basic concepts of which are understanding a language as a semiotic system and a means of reflection of the surrounding reality, the interaction of language and thinking, correlation of language and culture, etc.

The NCCB, being of cognitive semiotic nature and realized in the discursive space, plays a leading role in the process of socialization of the language personality and foresees the assimilation and representation of etiquette and ritual norms, national values, fixed as stereotypes and being dominant during a particular period of the development of societies. Thus, the language personality can be correlated with a certain socio-psychological phenomenon, represented by a bearer of consciousness and language with a stable system of socially significant traits, a complex inner (mental) world with a specific attitude to oneself and one's surroundings, which is realized in the relation with reality, other persons and themselves (Karaulov 1987, 2002).

The multidisciplinary nature of the cognitive semiotic phenomenon of cooperative communicative behaviour is linked with the category of cooperativeness, ontological and gnoseological status of which is based on the principles of establishing and maintaining equilibrium in interpersonal, social and group, social and economic inter- and transcultural relationships, which promotes constructivism in dealing with a diverse range of conflicts (domestic, family, partner, collective, professional, interethnic, ethnic, political, even religious, military, etc.) (Korolyov 2018a). Cooperativeness implicates and demonstrates the lack of egocentrism, prevents the emergence and spread of ethnocentrism, motivating a willingness to conduct a dialogue, facilitating the exchange of experience. The aftereffects and benefits of a successful NCCB in the process of mono- and intercultural communication lie in the fact that interactants are able to maintain a more stable position in relation to the interlocutors (partners, competitors, etc.), channelling pragmatically oriented efforts into cooperation, stimulating a further cooperation (Korolyov 2019).

National communicative behaviour is the formation of language/communicative consciousness and cognitive semiotic and discursive space within certain speech genres that are formed by a complex of discursive situations. At the same time, DP as semiotic (sign) constructs of communicative consciousness and components of discursive situations are representative of the discursive space, within which national communicative behaviour takes place (Korolyov 2020). Standardized formulas DP farewell refers to the most commonly used etiquette and ritual signs of the NCCB of the representatives of different ethnic cultures, through which the phatic closing phase of discursive situations is realized (the contact between the interlocutors is being ended; interaction is finalized) leading to defining the relationship of the addresser and the addressee in everyday life which is reflected in the discursive space of cooperative interaction. 


\section{Standardized formulas in the mode-organization of the discursive practice: farewell as an indication of communicative consciousness of Ukrainians, Russians, Lithuanians and Americans}

Relevant to the determination of the pragmatic specificity of the symbolic representation of the studied DP farewell in the NCCB of Ukrainians, Russians, Lithuanians and Americans is its differentiation on the basis of experimentally established PIs for nuclear, circumnuclear and peripheral (near and far) zones of modes of politeness/tolerance, neutrality and familiarity, reflected in the communicative consciousness. During further examination, it is necessary to establish the correlation of the PI of a certain DP and the level of possibility of its application in (non-)institutional discursive situations: the modes of politeness and tolerance, as a rule, correlate with official forms of interaction, while those of familiarity - with informal ones. The mode of neutrality in this sense is characterized by its universality, since it involves the use of the standardized formula of DP that remains relevant to it in all types of discourse.

As a result of linguistic interviewing, the PI (scale) of the modes of politeness / tolerance, neutrality and familiarity as regulators of the NCCB of Ukrainians, Russians, Lithuanians and Americans was determined - as an average index for each type of DP in a specific linguaculture, as well as for DP farewell (diagram).

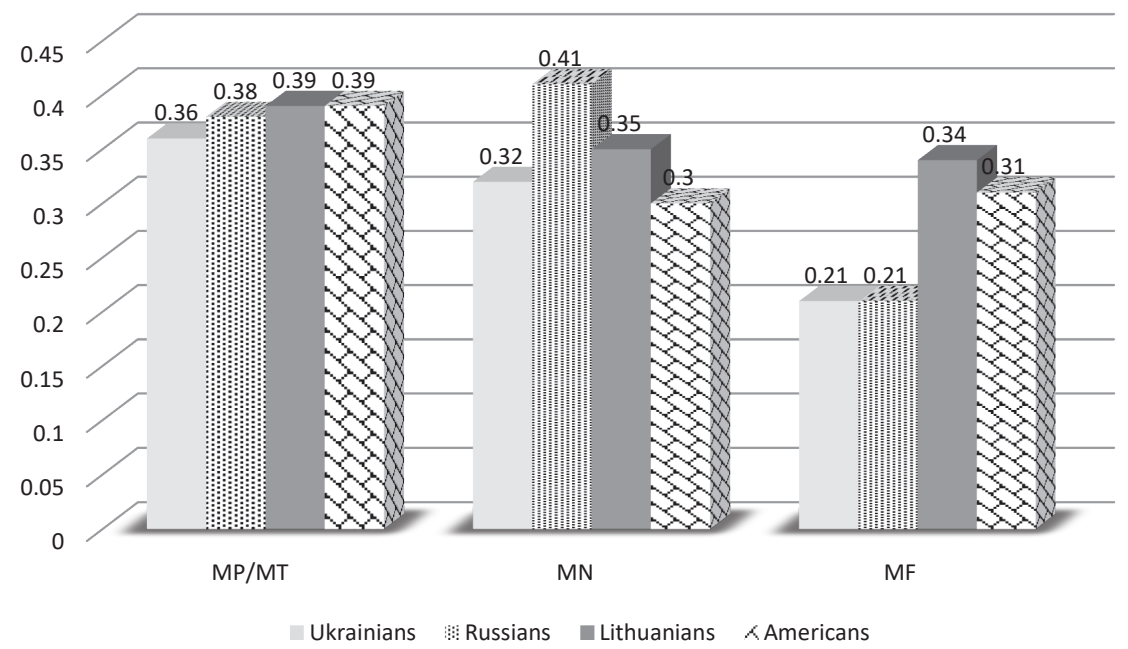

Diagram. Productivity indices of NCCB modes of Ukrainians, Russians, Lithuanians, and Americans in DP прощання / прощание / atsisveikinimas / farewell

The responses, obtained experimentally, form a certain kind of associative field with a nucleus, a circumnuclear zone and a periphery, which is differentiated into near and far ones. We relegate high-frequency reactions to the nuclear and circumnuclear zones, whereas to the zones of near and far periphery - lowfrequency ones. We consider responses to be high-frequency, if they rank from 
second to third. On average, such reactions account for $30 \%$ of the total number of responses to each stimulus notion. According to Yu. Karaulov, the rank index of the frequency of responses has a statistic pattern (Karaulov 1994, 24). The number of ranks is directly linked to the number of responses: the greater this number, the greater the number of ranks in the field. With a field of 100 reactions, the number of ranks ranges from 5 to 8 . This pattern is confirmed by the results of our study. The nuclear zone of communicative consciousness of subjects includes standardized formulas of cooperative DPs, which in each particular linguaculture are observed in the answers of more than $50 \%$ of respondents, the circumnuclear zone - from $30 \%$ to $50 \%$, the near periphery - from $10 \%$ to $30 \%$, and the far one up to $10 \%$ respectively.

Let us present empirical findings of the research in the form of psycho- and sociolinguistic experiments concerning the mode-organization of standardized formulas of DP farewell in the NCCB of Ukrainians, Russians, Lithuanians and Americans. It should be immediately noted that in all analysed linguacultures, the DP farewell occasionally overlaps with the DPs of wishes, apologies, gratitude / appreciation (see more in Korolyov 2018a).

Special attention will be paid to those standardized formulas of DP farewell, which in the analysed linguacultural contribute to the expression of the specificity of the mode-organization and the effectiveness of NCCB. For this purpose, we can show the overall average PI of each of the modes by specific communicative cultures, which primarily show specificity within the mode of familiarity: the MF circumnuclear zone in the communicative consciousness of respondents is pinpointed in Lithuanians - PI 0.34 and Americans - PI 0.31; the near periphery zone - in Ukrainians - PI 0.21, and in Russians - PI 0.21.

According to numerous researchers, including Sternin (2011), Larina (2009), whose study object has been the features of verbalization of farewell in Englishspeaking linguacultures, particularly in the American communicative behaviour, the variety of etiquette and ritual speech signs of farewell are much larger and more varied than in DP greetings (Sternin, Sternina 2001, 98). This concept is fully exemplified, since the highest PI of the mode of familiarity of DP farewell has been found in the American communicative culture due to the multifunctionality of these sign constructs in the communicative consciousness of Americans. One standardized formula of DP farewell in the American NCCB can be used with the identical PI within the range of all specified modes.

Thus, we must first refer to the invariant sign standardized formula of DP Bye (bye), (it's been a lot of fun / see you back)! - MP / MT 0.88; MN 0.99; MF 0.99, the modes of which form the nuclear zone in the communicative consciousness of subjects. Its variants Bye! and Bye-bye! are also cited as possible forms of contact termination in the three modes of NCCB of Americans, although more often they are supplemented by other utterances that play down their familiarity. However, we can explain the shift in the organization of modes of this DP standardized formula towards the communication modes of neutrality and politeness / tolerance through the processes of democratization of communicative interaction in the American society, which were already mentioned by researchers of discursive spaces of English-speaking linguacultures (Stupin, Ignatyev 1980, 126; Larina 2009, 189). 
Standardized formula of DP Bye! and Bye-bye! are contracts of a more formal farewell DP Goodbye! - MP / MT 0.85; MN 0.25, which, in turn, was formed from the God be with you form (Ferguson 1981, 33).

Notably, the standardized formulas of DP farewell, which have a religious semantics are found in the responses of subjects aged mostly over 40 of the four linguacultures analysed: God bless / save (you)! - MF 0.03; Su Dievu! / Tesaugo tave / Jus Dievas! - MP / MT 0.1; MF 0.08; С Богом! / Храни вас / Вас / тебя Господь / Боже! - MP / MT 0.14; MF 0.15; 3 Богом! / Бережи (тебе / Вас) Боже / Господь! - MP / MT 0.11; MF 0.12. The general tendency is that these standardized formulas of DP are relevant to the modes of politeness / tolerance and of familiarity, forming in the American and Lithuanian communicative cultures the zones of far periphery of the communicative consciousness of individuals, and in the Russian and Ukrainian ones forming the near one.

The similar tendency is demonstrated by the corresponding standardized formulas of DP farewell in the Lithuanian communicative culture, in particular, by the contracts of more formal utterances: 1) Iki! - MP / MT 0.18; MN 0.55; MF 0.99 from Iki pasimatymo! - MP / MT 0.95; MN 0.92; MF 0.17; 2) Viso! - MP / MT 0.15; MN 0.33; MF 0.96; from Viso gero! - MP / MT 0.92; MN 0.89; MF 0.64. PI of MP / MT allow stating that in the communicative consciousness of Lithuanians, representing medium and high status of the contemporary society, certain shifts in the organization of NCCB modes are occurring, which affect the functioning of etiquette and ritualized standardized formulas of DP. Instead, the variation of DP's farewell standardized formulas with formants iki and viso remains broad and branched: Iki (nauju) susitikimu!! - MP / MT 0.68; MN 0.54; MF 0.24; Iki rytojaus / kitu metu / kitos vasaros / žiemos / savaitès / kito pirmadienio [..]! MP / MT 0.68; MN 0.64; MF 0.43; Iki / ligi greito / malonaus / laukiamo / sutarto pasimatymo / susitikimo! - MP / MT 0.49; MN 0.46; MF 0.38; Iki susitikimo namie / Klaipédoje / sekmadieni / [..]! - MP / MT 0.48; MN 0.52; MF 0.22; Viso geriausio! - MP / MT 0.55; MN 0.38; MF 0.21; Viso labo! - MP / MT 0.54; MN $0.42 ;$ MF 0.22 etc.

In the Russian linguaculture, the standardized formula of DP Пока(пока)! MN 0.87; MF 0.99 is the equivalent of the American formula Bye (bye)!, and the Lithuanian one Iki! (although in the Lithuanian language it is a pronoun to which, of course, in the role of DP Farewell formula, has lost its grammatical form and part-of-speech appurtenance, while performing the function of exclamation), but according to the PI of modes, it is not characteristic of institutional discursive space, because it forms the nuclear zone of the communicative consciousness of individuals only within the modes of neutrality and familiarity. Let us note that such a colloquial variant as the standardized formula of DP Покеда / покедова! - MF 0.12 already constitutes the zone of the near periphery of the mode of familiarity in the communicative consciousness of Russian informants, and the DP formula Пana! - MF 0.06 constitutes the zone of far periphery.

The Ukrainian communication culture is characterized by the active use of the standardized formula of DP Пока (пока)! - (MN 0.39); MF 0.99, which forms the circumnuclear and nuclear zones within the modes of neutrality and familiarity, respectively. However, no response was recorded within the MP / MT, indicating 
low performance of its use within these modes of the Ukrainian discursive space. However, following the current trends in the American and Lithuanian linguacultures, in which the development of democratic values related to the equality of rights of all the members of the society and freedom of expression has commenced and continues to evolve, we can expect the corresponding shifts in the communicative consciousness of Ukrainians in the near future.

For example, such specific for the Ukrainian NCCB standardized formulas of DP farewell, as: Будьмо! - MP / MT 0.26; MN 0.16; MF 0.18; Бувай-те / будьте (здоровий(a,i) / щасливий(a,i)! - MP / MT 0.22; MN 0.33; MF 0.48 are already fixed in the mode of politeness / tolerance, forming a zone of near periphery in the communicative consciousness of Ukrainians; the DP formula $\Pi a-n a !$ - MN 0.07; MF 0.24 constitutes zone of far periphery for the mode of neutrality, and of near periphery - for the mode of familiarity, which already testifies to a certain shift in the organization of modes of NCCB of Ukrainians in the discursive situation farewell.

The studied linguacultures show a common and universal tendency for ending contact when the function of standardized formulas of DP farewell is fulfilled by the formulas of DP wishes:

Ukr.: Удачі (тобі / Вам)! - MN 0.15; MF 0.17; Щасливо / щасти (тобі / Вам) / (не)хай щуастить! - MP / MT 0.31; MN 0.24; MF 0.36; На все добре! MP / MT 0.75; MN 0.77; MF 0.11; Усього (тобі / Вам) найкращяого / доброго, найліпшого! - МP/MT 0.53; MN 0.42; Гарного / присмного дня / вечора! - MP / MT 0.4; MN 0.17; Гарного(ої,их) / приємного(ої,их) / щасливого(ої,их) / веселоого(ої,их) вихідних / свят / вікенду / відпустки / подорожі / дороги! - MP / MT 0.26; MN 0.18; (На) добраніч / доброї / спокійної ночі! - MP/MT 0.14; MN 0.1; MF 0.06; Бувай-те / будьте (здоровий(a,i) / щзасливий(a,i)! - MP / MT 0.22; MN 0.33; MF 0.48;

Rus.: Удачи (тебе / Вам)! - MP / MT 0.21; MN 0.43; MF 0.32; Счастливо (тебе / Вам)! - MP / MT 0.38; MN 0.29; MF 0.24; Всего (Вам / тебе) (самого)доброго / хорошего / лучшего!-MP / MT0.75; MN0.71; MF 0.15; Хорошего / удачного / приятного дня / вечера! - MP / МТ 0.46; MN 0.49; MF 0.13; Хорошего(ей,ux) / приятного(ой,ых ) / счастливого(ой,ыхx) / весёлого(ой,ьхх) / удачного(ой,blх) отпуска / поездки / дороги / выходных / праздников / уикенда [..]! - MP / MT 0.34; MN 0.36; MF 0.15; Спокойной / доброй ночи! - MP / MT 0.19; MN 0.16; MF 0.15; Сладких / приятных / добрых сновидений! - MN 0.08; MF 0.03; Споки! -MF 0.02; Будь-те здоров $(a, b l)$ / счастлив(-a,-bl)! - MP / MT 0.18; MN 0.19; MF 0.08;

Lith.: Viso gero! - MP / MT 0..92; MN 0..89; MF 0..64; Viso! - MP / MT 0..15; MN 0..33; MF 0..96; Viso geriausio! - MP / MT 0..55; MN 0..38; MF 0..21; Viso labo! - MP / MT 0.54; MN 0.42; MF 0.22; Sèkmés (tau / Jums)! MP / MT 0.86; MN 0.74; MF 0.77; Laimingai! - MP / MT 0.92; MN 0.85; MF 0.86; Geru / gražiu / laimingu / smagiu švenčiu / atostogų! Gero / gražaus / smagaus savaitgalio / poilsio! - MP/MT 0.16; MN 0.19; MF 0.18; Laimingo kelio! - MP / MT 0.2; MN 0.17; MF 0.15; Geros / gražios dienos [..]! - MP / MT 0.19; MN 0.16; MF 0.2; Geros kelionès ir laimingai 
sugrįžti! - MP / MT 0.15; MN 0.04; Labanaktis! / Labos naktelès! - MP / MT 0.21; MN 0.16; MF 0.18; Saldžiu sapnų! / Gero miego! - MP / MT 0.16; MN 0.19; MF 0.2; Tegu lydi visur sèkmè! - MP / MT 0.12; MN 0.08; MF 0.03; Bükite / lik-ite sveikas(a,i,os)! - MP / MT 0.14; MN 0.1; MF 0.18; Gyvenkim / darbuokimés sveiki! - MN 0.02; MF 0.03;

Amer.: (Good) night! - MP / MT 0.16; MN 0.15; MF 0.01; (Have nice) / sweet dreams! - MN 0.06; MF 0.11; Good luck! - MP/MT 0.32; MN 0.35; MF 0.47; Be happy! - MN 0.38; MF 0.44; Take care (of yourself / yourselves)! - MN 0.11; MF 0.18; (Have a) nice / good day / evening / stay [..]! - MP / MT 0.15; MN 0.3; MF 0.25; Have a happy / good / nice / pleasant / merry holidays / weekend / safe journey [..]! - MP / MT 0.53; MN 0.48; MF 0.44.

The communicative cultures under consideration are also characterized by standardized formulas of DP farewell that simultaneously fulfil the pragmatic function of DP gratitude / appreciation, which are usually added to the proper etiquette units with the semantics of 'farewell' and express gratitude for the invitation or visit, for their time, for treating or other tokens of appreciation:

Ukr.: (Я / ми) щчиро / охоче / дуже / сердечно / красно дякую(ємо) / вдячний(а,i) (тобі / Вам / вам) за увагу / зустріч [..]! - MP / MT 0.16; MN 0.12;

Rus.: (Большое / огромное) спасибо / (сердечно / искренне) благодарю(им) за внимание / встречу / [..]! - MP / MT 0.4; MN 0.36;

Lith.: (Labai / nuoširdžiai / nepaprastai) dèkingas(a,i) (Jums / tau / jums) / ačiū / dèkui / dèkoju(ame) už susitikima / dèmesị / [..]! - MP / MT 0.18; MN 0.15;

Amer.: Thank you/thanks (for having us / for a lovely/wonderful evening / meal / time / [..])! - MP / MT 0.38; MN 0.35; MF 0.35.

A special universal phenomenon for the studied communicative cultures group of the standardized formulas of DP farewell are signs-constructs of intentional nature, which semanticise the intention of communicators to continue contact in the future:

Ukr.: До (скорого / швидкого / наступного) побачення! - МP / МТ 0.98; MN 0.99; MF 0.17; До завтра / наступного(i) тижня / понеділка / року / літа / зими [..]! - МР / МТ 0.76; MN 0.87; MF 0.18; До (настуnної / скорої) зустрічі (враниј /вдень/увечері / вдома / в Києві / в неділю [..])! - MP / MT 0.78; MN 0.77; MF 0.35; Я/ми ненадовго / не прощаюсь(смось)! - $\mathrm{MN}$ 0.13; MF 0.05; (Ще) побачимось / зустрінемось(чаємось) о шостій годині / на роботі / в кафе [..]! MP / MT 0.25; MN 0.23; MF 0.21; (Я) зателефоную / подзвоню / наберу / напишу! / (Ти / Bu) телефонуйте / дзвони(imb) / пиши(imb)! / На зв'язку! / Тримаймо зв'язок! - MN 0.3; MF 0.27;

Rus.: До (скорого / следующего) свидания! - MP/MT 0.98; MN 0.99; Дозавтра / следующего(й) года / недели / зимы / лета / [..]! MP / MT 0.73; MN 0.89; MF 0.18; До (скорой / следующей) встречи (дома/в СанктПетербурге / в воскресенье /утром/днём/ вечером / [..])! - MP / MT 0.77; MN 0.67; MF 0.21; Я / мы ненадолго / не прощзаюсь(емся)! - МР / MT 0.11; MN 0.17; MF 0.19; (Ещё) увидимся / встретимся(чаемся)/пересечёмся (в три часа/на работе/в 
(торговом) иентре [..])! - MP/MT 0.42; MN 0.67; MF 0.37; (Я) позвоню / напишу! (Tbl / Bbl) звоните / пишите! / На связи! - MN 0.23; MF 0.25;

Lith.: Iki pasimatymo! - MP/MT 0.95; MN 0.92; MF 0.17; Iki (nauju) susitikimu! - MP / MT 0.68; MN 0.54; MF 0.24; Iki susitikimo namie / Klaipédoje / sekmadieni / [..]! - MP / MT 0.48; MN 0.52; MF 0.22; Iki / ligi greito / malonaus / laukiamo / sutarto pasimatymo / susitikimo! - MP / MT 0.49; MN 0.46; MF 0.38; Iki rytojaus / kitu metu / kitos vasaros / žiemos / savaités / kito pirmadienio [..]! - MP/MT 0.68; MN 0.64; MF 0.53; Susitiksime trečia / darbe / (prekybos) centre / [..]! - MP / MT 0.41; MN 0.38; MF 0.25; Iki! - MP / MT 0.18; MN 0.55; MF 0.99; (Ǎ̌) paskambinsiu / parašysiu! / (Tu / Jus) skambinkite / parašykite! / Susirašysim(e)! - MN 0.18 ; MF 0.2;

Amer.: (I'll / we'll) see you soon / be seeing you / tomorrow / later / then / again / around / in a bit / in week / in the morning / in weekend / on Sunday / at home / in New York / at the office / at 6 / on work / in café [..]! - MP / MT 0.85; MN 0.87; MF 0.95; Text / call me! Keep in touch! - MN 0.36; MF 0.4; Bye (bye). (it's been a lot of fun / see you back)! - MP / MT 0.88; MN 0.99; MF 0.99; See ya! - MF 0.34; Bye for now! - MN 0.12; MF 0.25; See you one more time! - MN 0.07; MF 0.14; Catch you later! / I'll ring you later! I I'll give a ring one of these days! - MN 0.12; MF 0.15; Don't hesitate to call / write / message! - MP / MT 0.26; MN 0.03; MF 0.17;

In the cooperative communicative behaviour of Ukrainians, Russians, Lithuanians, and Americans within of the standardized formulas of DP farewell there are those that duplicate DP invitation but which usually refer to the addresser's proposal to return a visit:

Ukr.: (Наступного разу / пізніше / тепер) (я / ми) чекаю(ємо) (тебе / вас / Bac) / (mи / ви / Bu) приходь(те) до мене / нас / (mи / ви / Ви) масм(те) (обовлязково) до мене / нас прийти / завітати! - MP / MT 0.34; MN 0.32;

Rus.: (Теперь / в следующий раз / позже) (я / мы) жду(ём) (тебя / Вас) / (mы / вы / Bbl) приходи(те) к(о) мне / нам / (ты / вы / Bbl) должен(ны) (обязательно) к(о) мне / нам прийти! - MP / MT 0.28; MN 0.27;

Lith.: (Vèliau / kita karta / kitu laiku) lauk(s)iu((s)im(e) / ateikite pas mane / mus [..])! - MP / MT 0.15; MN 0.17; MF 0.07;

Amer.: (Next time / later / one day) come to me / us / you should come to lunch / you must come around to my house! - MP / MT 0.23; MN 0.2.

Common for the analysed communicative cultures are the standardized formulas of DP farewell, which duplicate DP request and semanticise the tokens of appreciation for third parties, who are not directly involved in communication:

Ukr.: (Переда(ва)йте) привіт / вітання батькам / родичам / чоловікові / [..]! / (Усім) привіт / вітання! - МP / МТ 0.15; MN 0.18; MF 0.2;

Rus.: (Переда(ва)йе) привет / поздравления родителям / жене / детям / [..]! (Всем) привет! - MP / MT 0.21; MN 0.32; MF 0.3;

Lith.: (Perduokite) (mano / mūsu) linkejjimus draugams / vyrui / vaikams [..]! / Linkejimai visiems! - MP / MT 0.16; MN 0.24; MF 0.14; 
Amer.: Say hi / hello to John / your wife / [..]! / (Give my) regards to your parents! / (Convey my) congratulations to Jack! / Best wishes to Melany! MP / MT 0.18; MN 0.21; MF 0.2.

Thus, the various sign configurations of the standardized formulas of DP farewell in the studied communicative cultures perform a phatic function and are primarily of etiquette nature, preconditioning a favourable atmosphere of communication, as communicants express respect for each other through ritualistic good wishes, which etymologically contain the wishes of health, good day, good luck, etc. The dominant standardized formulas of DP farewell in configuration with other DPs as the sign constructs of the communicative consciousness of Ukrainians, Russians, Lithuanians, and Americans are predetermined by their use in (non-) institutional discursive situations, as well as socio-anthropometric, psychological, gender, and other characteristics of interactants, etc.

\section{Conclusions}

Summarizing the comparative analysis of the standardized formulas of DP farewell, let us note that they are universal signs of the studied linguacultures, but with different variations of modes in NCCB. Let us try to explain the higher degree of productivity and, consequently, the efficiency of the mode of familiarity in the NCCP of Americans and Lithuanians, compared to that of Ukrainians and Russians that are conditioned by such factors.

1. First of all, we focus on the anthropometric, sociocultural characteristics of informants, their educational grounding, etc., since psycho- and sociolinguistic experiments in the form of linguistic interviewing were conducted mainly among the respondents having medium and high social status.

2. The advantage of the standardized formulas of DP farewell of the mode of familiarity in NCCB of Americans and Lithuanians, compared with Ukrainians and Russians, can be explained by the greater extent of manifestation of democratic values, which at some stage of their formation influenced the specificity of speech interaction in institutional discursive space bringing it closer to the character and semiotics of a noninstitutional one. If we rely on the value dominants found in the communicative consciousness of the representatives of the linguacultures under study, which are common to Americans and Lithuanians, we should first of all emphasize equality and, above all, freedom of expression as necessary components of their cooperative speech behaviour and the factors pertaining to realization of their macrostrategy.

3. Another extralinguistic factor that, in one way or another, influences the dominant modes of cooperative communication in different communicative cultures may be the globalization processes and the development of information technologies. In this context, we should not ignore active migration processes, which are still active in the Republic of Lithuania, especially after the accession of this country to the European Union in 2004. The development of democratic institutions with the corresponding criteria and values of the "Western" type, the need for harmonious integration with the pan-European political, financial and economical, educational and cultural 
continuum, etc., urged the representatives of Lithuanian linguaculture to find effective ways and methods, in particular, of successful implementation of cooperativeness in the communicative interaction, which surely also affected their monocultural communication.

In the Ukrainian and Russian linguacultures, the mode of familiarity (which is distinguished from the familiar style of communication) is also present in the standardized formulas DP farewell, but it has a much lower PI than in the American and Lithuanian forms, and therefore a lower performance, which can be explained by the greater etiquette ritualization, adherence to the established norms and strict rules, as well as the existence of the rudiments of a former purely totalitarian (and not democratic) ideology. However, it should be noted, that due to modern information technologies that allow the communication process to become not only mono- and intercultural but also transcultural, there is a mutual influence of communicative consciousnesses when one and the same linguaculture can be both a recipient and a source.

4. An important factor, which also affects the higher PI of the mode of familiarity of the standardized formulas of DP farewell in NCCB of Americans and Lithuanians, is the principle of economy of speech / expressive efforts, which allows saving time in the process of communication in order to achieve the desired perlocutionary effect and the implementation of cooperative macrostrategy. This factor confirms the presence of national value dominants of agentness and vigour in the communicative consciousness of Americans and Lithuanians with an emphasis on their economic component (veiklos principas, orientacija $i$ versla, ekonomine veiklą; activity) та прагматизмі (pragmatizmas; pragmatism).

\section{Abbreviations}

$\begin{array}{ll}\text { Amer. } & \text { Americans } \\ \text { DP } & \text { discursive practice } \\ \text { Lith. } & \text { Lithuanians } \\ \text { MF } & \text { mode of familiarity } \\ \text { MN } & \text { mode of neutrality } \\ \text { MP } & \text { mode of politeness } \\ \text { MT } & \text { mode of tolerance } \\ \text { NCCB } & \text { national cooperative communicative behaviour } \\ \text { PI } & \text { productivity indices } \\ \text { Rus. } & \text { Russians } \\ \text { Ukr. } & \text { Ukrainians }\end{array}$

\section{References}

1. Alefirenko, Nikolay. 2007. Kognitivnaya semiologiya: istoki, stanovleniye i perspektivy razvitiya. Izvestiya Yuzhnogo federalnogo universiteta. Filologicheskiye nauki. 1-2, 143-152.

2. Darginavičienė, Irena. 2019. Multimodality in communication. Logos. 98, 146153. 
3. Dridze, Tamara. 1996. Sotsialnaya kommunikatsiya kak tekstovaya deyatelnost $\mathrm{v}$ semiosotsiopsikhologii. Obshchestvennyye nauki i sovremennost. 3, 145-152.

4. Ferguson, Charles A. 1981. The structure and use of politeness formulas. Conversational routine: explorations in standardized communication situations and prepatterned speech. Coulmas, Florian (ed.). The Hague, Paris, New York: Mouton Publishers, 21-35.

5. Foster, Dean. 2004. Europos šaliu etiketas. Vilnius: Algarvè.

6. Hymes, Dell. 1972. On communicative competence. Sociolinguistics. Selected readings. Pride, John Bernard, Holmes, Janet (eds.). Harmondsworth: Penguin, 269-293.

7. Kalnača, Andra, Lokmane, Ilze. 2018. Syntactic and pragmatic functions of the Latvian indeclinable participle in -ot(ies). Valoda: nozime un forma. 9. Gramatika un pragmatika. Kalnača, Andra, Lokmane, Ilze (eds.). Rīga: LU Akadēmiskais apgāds, 96-111. https://doi.org/10.22364/vnf.9.8

8. Karaulov, Yuriy. 1987. Russkiy yazyk i yazykovaya lichnost. Moskva: Nauka.

9. Karaulov, Yuriy. 1994. Ot struktury assotsiativnogo slovarya k strukture yazykovoy sposobnosti. Vestnik Rossiyskogo universiteta druzhby narodov. 1, 15-26.

10. Karaulov, Yuriy. 2002. Russkiy assotsiativnyy slovar kak novyy lingvisticheskiy istochnik i instrument analiza yazykovoy sposobnosti. Russkiy assotsiativnyy slovar. 1. Moskva: AST, 750-782.

11. Korolyov, Igor. 2018a. Nacionaljna kooperatyvna komunikatyvna povedinka: vid koghniciji do dyskursu. Kyiv: Kyjivsjkyj universytet.

12. Korolyov, Igor. 2018b. Freymovo-stsenarnaya semioticheskaya model natsionalnogo kooperativnogo kommunikativnogo povedeniya ukraintsev, russkikh, litovtsev i amerikantsev. Res Humanitariae. 23, 218-234.

13. Korolyov, Igor. 2019. Cognitive and communicative category of cooperativity: ontological and gnoseological status. Logos. 98, 83-93. https://doi.org/10.24101/ logos.2019.09

14. Korolyov, Igor. 2020. Discursive practices as sign constructs of communicative consciousness. Logos. 102, 61-69. https://doi.org/10.24101/logos.2020.07

15. Korolyov, Igor, Domylivska, Liudmyla. 2020. Mentality and national character as semiotic regulators of communicative behavior. Journal of History Culture and Art Research. 9(1), 354-364. http://dx.doi.org/10.7596/taksad.v9i1.2355

16. Krasnykh, Viktoriya. 2004. Analiz diskursa v svete kontseptsii freym-struktur soznaniya. Kulturnyye sloi vo frazeologizmakh $i v$ diskursivnykh praktikakh. Teliya, Veronika (ed.). Moskva: Yazyki slavyanskoy kultury, 243-245.

17. Larina, Tatjana. 2009. Kategoriya vezhlivosti i stil kommunikatsii. Sopostavleniye angliyskikh $i$ russkikh lingvokulturnykh traditsiy. Moskva: Rukopisnyye pamyatniki Drevney Rusi.

18. Lauze, Linda. 2018. Atbildes uz jautājumiem mutvārdu tekstā: pragmatiskais aspekts. Valoda: nozīme un forma. 9. Gramatika un pragmatika. Kalnača, Andra, Lokmane, Ilze (eds.). Rīga: LU Akadēmiskais apgāds, 168-177. https://doi. org/10.22364/vnf.9.12

19. Likhacheva, Alla. 2017. Russkaya kommunikativnaya kultura i eye verbalnyye proyavleniya: v sopostavlenii s litovskoy i drugimi kommunikativnymi kulturami. Vilnius: Vilniaus Universiteto Leidykla. 
20. Luriya, Aleksandr. 1998. Yazyk i soznaniye. Seriya: Psikhologicheskiye etyudy. Khomskaya, Evgeniya (ed.). Rostov-na-Donu: Feniks.

21. Mikhalchenko, Vida. 1984. Problemy funktsionirovaniya $i$ vzaimodeystviya litovskogo i russkogo yazykov. Vilnius: Mokslas.

22. Nikolayeva, Tatiana. 2000. Ot zvuka k tekstu. Moskva: Yazyki russkoy kultury.

23. Papaurèlytė-Klovienè, Silvija. 2007. Lingvistinès kultūrologijos bruožai. Šiauliai: Šiaulių universiteto leidykla.

24. Pocheptsov, Georgiy. 2001. Teoriya kommunikatsii. Moskva: Refl-buk; Kiev: Vakler.

25. Sedov, Konstantin. 2004. Diskurs i lichnost: evolyutsiya kommunikativnoy kompetentsii. Moskva: Labirint.

26. Sheygal, Elena. 2000. Semiotika politicheskogo diskursa. Moskva; Volgograd: Peremena.

27. Shutova, Mariia. 2016. Etnokulturni stereotipni portreti angliytsiv i ukraintsiv (kognitivno-onomasiologichna rekonstruktsiya frazeoformul). Kyiv: Vidavnichiy tsentr KNLU.

28. Sternin, Iosif. 2008. O ponyatiyakh metod, metodika, priyem. Voprosy psikholingvistiki. 7, 24-25.

29. Sternin, Iosif. 2015. Leksicheskoye znacheniye slova v rechi. Moskva, Berlin: Direkt-Media.

30. Sternin, Iosif, Sternina, Marina (eds.). 2001. Amerikanskoye kommunikativnoye povedeniye. Voronezh: Izdatelstvo Voronezshskogo gosudarstvennogo universiteta.

31. Stupin, Leonid, Ignatyev, Konstantin. 1980. Sovremennyy angliyskiy rechevoy etiket. Leningrad: Leningradskiy gosudarstvennyy universitet.

32. Vasko, Roman. 2019a. Semiotic and culturological passportization of numeric phraseosymbols. Logos. 98, 94-103.

33. Vasko, Roman. 2019b. Reflection of the ancient rituals semiotics in cultural etiquette forms of politeness. Logos. 100, 85-94.

34. Yagunova, Elena. 2005. Eksperiment v psikholingvistike: Konspekty lektsiy $i$ metodicheskiye rekomendatsii. Sankt-Peterburg: Ostrov.

\section{Kopsavilkums}

Rakstā aplūkotas atvadīšanās diskursa prakses standartformulas ukraiṇu, krievu, lietuviešu un amerikāṇu nacionālajā kooperatīiās saziṇas uzvedībā. Šo formulu gramatizēšanās ir atkarīga no konkrētas lingvokultūras un diskursa prakses. Diskursa prakses formula atvadīšanās pētījumā tiek uzskatīta par standartveida etiḳeti un radošu rituāla konstrukciju, ko lieto ukrainini, krievi, lietuvieši un amerikāṇi, lai noteiktā situācijā īsi noslēgtu diskursu.

Rakstā piedāvāta jauna eksperimentāla pieeja atvadī̌sanās diskursa prakses standartformulu identificēšanā četru lingvokultūru materiālā. Lingvistiskajā eksperimentā atklāti pieklājības / tolerances, neitralitātes un familiaritātes veidi katrā minētajā lingvokultūrā saistī̄āà ar atvadīšanās frāzēm. Tāpat aplūkotas kopīgas un atšķirīgas atvadīšanās frāžu lietojuma iezīmes četrās lingvokultūrās.

Atslēgvārdi: atvadīšanās diskursa prakse; standartformula; nacionālā kooperatīvās saziņas uzvedība; pieklājības veidi; tolerances veidi; neitralitātes veidi; familiaritātes veidi. 